\title{
“Critical Legal Histories Revisited": A Response
}

Robert W. Gordon

The author responds to comments reappraising "Critical Legal Histories" (CLH) (1984). CLH critiqued "evolutionary functionalism," the idea that law is a functional response to a typical modernizing process. CLH argued that "society" was partly constituted of legal elements and that law was too indeterminate to have reliably regular functional effects. CLH has been misinterpreted as calling for a return to internal histories of "mandarin" doctrine: all it said was that some doctrinal histories were valuable, without privileging them. This response clarifies that the relations of law to society and social change, and of high-level official law to everyday local law are distinct issues. CLH is mostly moot today, since social-legal historians have incorporated its insight that legal concepts are embedded in everyday social practice. But other fields have revived deterministic Whiggish accounts of progressive development and of law functional to it-to which CLH's critique still seems relevant.

It is of course very gratifying that anyone should think that an article written over twenty-five years ago might still be worth reading, and even organize a symposium around. (It is also rather discomfiting, since it is hard to say what one dreads most to find in the old stuff: evidence of youthful folly or, worse, evidence that one was wiser and better with words a long time ago.) I am moved beyond measure by the perceptiveness and seriousness of these comments from critics who are also friends.

For the reader of this piece, including the reader who was once its writer, one of the challenges is to try to reconstruct what the piece was trying to say to its intended audience. If there is one point above all others that historians, certainly including legal historians, have been trying to get across to lawyers for centuries now, it is surely the basic precept of historicism, that a social practice or document is a product of the preoccupations of the people of its own time and place, and that if it survives to be reenacted or reread at a later time, it will acquire a new set of meanings from its new context, new adherents and new instrumental purposes and consequences.

To take the historical inquiry first: What (do I now think) this piece was trying to say? It didn't have a single message. The main purpose was to describe and critique a grand theory, embodied in a series of grand narratives, of the social origins and functions of law: the piece called this "evolutionary functionalism" (EF). The theory has two components. The first (the "evolutionary" part) is that there is a process of social development common to most "advanced" or "dynamic" societies, culminating in modernity: liberal-capitalist forms of economic organization; liberal-constitutional-

Robert W. Gordon is Professor of Law, Stanford University; Chancellor Kent Professor of Law and Legal History, Emeritus, Yale University. Thanks to the symposium contributors and participants in legal history workshops at the University of Michigan and University of Toronto for valuable comments. 
democratic forms of political organization, sacred to mostly secularized cultures; and "status-to-contract," liberation of persons from social roles defined by birth, clan, local place and customs, and traditions of thought and belief to become mobile, freely contracting, and self-expressing individuals. Nobody ever thought this modal form was universal: some societies have deviated into fascism, others into communism; still others reverted to theocracy or virulent ethnic nationalism, and many have simply stagnated in traditional or primitive phases.

Some such narrative of social evolution is common to most of the great schools of post-Enlightenment social thought: Adam Smith's stage theory of hunter followed by pastoral and commercial forms of society; Marx's primitive-accumulation-to-feudalismto-capitalism-to-socialism; and modernization theories from Weber, Spencer, and Durkheim to the present day (see generally Burrow 1966; Aron 2004; Stein 1980). Although similar in their description of typical sequential stages of social order, the theories differ considerably in their details: Adam Smith's account of the fall of feudalism (Smith 1776, Book III) is a story full of irony and contingency and unexpected consequences, in contrast to many modern accounts such as Walt Rostow's Stages of Economic Growth (Rostow 1960), which arranges "all societies, in their economic dimensions, as lying within one of five categories: the traditional society, the preconditions for take-off, the take-off, the drive to maturity, and the age of high massconsumption." In general, I think it is a fair criticism of my account of EF in CLH that in collapsing so many different theories of legal-social change, expounded over two centuries, into common elements, I paint a picture of modernization theories that is as reductive as I claim are their pictures of modernization. ${ }^{1}$

The second (the functionalist part) is that law and legal systems are best understood as facilitative technologies that are adaptive responses to social needs and demands resulting from these modernizing processes: law basically follows evolving custom. Some writers on law gave credit to law as a leading force in social development (law "facilitated" or "enabled" important social changes), but most believed it to have been a lagging sector (changes produced new demands, which law gradually began to supply). Law in these mainstream accounts is largely a dependent variable, although in virtually every important theory the law that arises to serve social needs is seen to have some autonomous reciprocal effect on general development, if only that of channeling the direction, or somewhat retarding the pace, of further social change (for classic examples, see Pound 1909; Hurst 1956, 71-108). Basic underlying social change announces what kind of law is needed to promote it, and the legal system-albeit with grumbles and lags and frictions-responds by producing such law. Modern societies need property rules to secure against private invasion and state confiscation, as well as rules promoting alienation and preventing dynastic inheritance; legal regimes that externalize costs of infant industries by limiting liability for harms; predictable contract enforcement; entrenched guarantees of protection against political persecution. In Marxist accounts, capitalist societies need property laws that permit the expropriation of peasant proprietors to accumulate capital and create an industrial reserve army; formally free contract law that enables the sale of commodities, including labor, free of

1. For recent fine work that valuably brings out important differences in lawyers' theories of legal-social change, see Siegel (1990), Parker (2011), and Rabban (2010). 
feudal and mercantilist controls; and labor and criminal laws that inhibit the capacity for collective action of working classes. The law comes up with ways of providing for such needs.

Again, such accounts vary greatly in their degree of determinism, how tight a connection they see between the society's development needs and the law's adaptive responses. Sometimes the law produces rules adapting to social demands by an almost automatic mechanism, as in the theories of modern Chicago economists that the common law is "efficient" (see Rubin 1977). Sometimes, as in Adam Smith's and perhaps also Max Weber's (see Trubek 1972) accounts, the evolution of legal institutions is the contingent outcome of mostly autonomous conflicts, events, and intellectual trends, which just happened to result in law conducive to economic modernization. Naturally, to the extent legal development is seen as relatively autonomous from other kinds of social—especially economic - development, it is also less of a dependent variable.

I believed then, and still do, that this theory and its accompanying narrative had dominated Western thinking about the relation between law and social change for the last two centuries, although in strictly legal writing the theory is usually inexplicit: it lurks as a set of background assumptions rather than being explicitly set forth and argued for.

Whether "law" is leading or "lagging," it is pictured in narratives of modernization as something related to, but separate from, the larger processes of social change: a secondary specialized subsystem of society, being worked on by social change and working back on it. Of course, nobody could deny that much of what we call law and legal systems are specialized activities taking place in specialized institutions (courts, administrative agencies, legislatures, etc.) populated by specialized social actors (lawyers, judges, and other officials). But the distinctive and specialized institutions, enactments, procedures, and officials that we call "the legal system" hardly account for most of the ways in which law and legal norms work their way into everyday consciousness and social processes. So another purpose of this piece was to try to capture, as many legal sociologists, anthropologists, and historians have tried to do, an alternative way of thinking about law-society relations from that of an autonomous (or "relatively autonomous") legal system interacting with a larger social system so as to manage or facilitate or regulate that social system's affairs.

EF describes a relationship between two spheres of social life, the big sphere of society (the economy, family life, technological and demographic change, contests for political power, etc.) and the smaller dependent sphere of the legal system. But one cannot describe the social sphere independently of its constitutive legal elements, such as property rights and contracts and the expectation of routine legal enforcement and legally permitted self-help enforcement (which allows my private security force to enforce my rules on my property with lethal force if needed, or, as a condition of going to work for me or buying my product, allows me to require you to sign a contract that deprives you of any effective remedy for its violation) is much more than the activities of the official legal system. Asked to describe the key economic order of modernity, "capitalism," people usually come up with phrases like "freely marketable [or transferable by gift or inheritance] property rights" or "formally free labor." But these aren't simply legal rules and regimes that facilitate capitalism; they are capitalism, or key elements of it, anyway. 
So an alternative conception to functionalism has over the years come to be called—rather mystifyingly and not always helpfully—a "constitutive" theory of lawsociety relations, or a "mutually constitutive" theory: law (partially) constitutes society and society constitutes law. Property, contract, company, slave, employee, nation-state, illegal immigrant, criminal, husband, wife, adopted child, creditor, bankrupt - these are all legal concepts, but also lived social realities and identities.

The third piece of the critique of $\mathrm{EF}$ was that the connections hypothesized between "legal" and "social" change, even when they were not partly tautological (as in "law facilitated the rise of capitalism"), could not be strong causal links because the "law" in the dominant legal-social accounts was too underspecified and indeterminate to entail any definite set of social consequences. Saying things like "the negligence principle" or "property rights in land" were preconditions to, or even just very favorable legal environments for, economic growth, ignored the basic insight of Legal Realism - the myriad ways in which legal doctrines can be interpreted and differentially applied or ignored or worked around or resisted on the way to enforcement. There are respects in which it is equally valid to say "the American legal system laid the foundation for economic growth by creating enforceable property rights" and "the American legal system laid the foundation of economic growth by destroying preexisting property rights" (e.g., by allowing slaveowners to extinguish property in labor and colonizers to steal Indian titles, enclosers to eliminate use-rights in commons, canal and railroad developers to cut rights of way through farmland, squatters to acquire title from absentee owners). Comparative legal-social history, moreover, usually revealed many alternative legal paths to modernity, as well as variant types of modernity.

My final purpose was much more local and immediate, and somewhat incidental to the main project. The piece (CLH) appeared in a symposium on critical legal studies, and I used it to set forth and explain to an audience of what I expected were probably skeptical readers, coming from social-legal history and the law-and-society movement, a particular type of legal history-mostly doctrinal history, as it happened - then being written by scholars affiliated with the CLS movement. I wanted to show that this new doctrinal history of legal fields structured by "contradictions" was not a reactionary reversion to traditional "internal" modes of legal historiography, but an interesting and illuminating way of approaching the social study of legal consciousness. In fact, I thought, this particular type of doctrinal history was an especially efficient tool for helping dissolve notions of legal functionalism, for if the law were rooted in such structural contradictions, it could inherently be made functional to radically divergent forms of social ordering. I also tried to argue that the field of research into this type of history had been counterproductively limited to elite, or "mandarin," legal materials and that it would benefit greatly from expanding its range outward and downward into "vernacular" deployments of legal concepts and categories.

The very generous and helpful comments of Susanna Blumenthal, Laura Edwards, and Chris Tomlins raise some very provocative questions about some of the points I made in CLH and cause me to wonder whether they were valid then and are still valid now, or wrong when made or proved wrong since. They also provoke reflection on how the field of legal history has changed since 1984 .

Tomlins gives a favorable account of critical legal studies generally as having changed conversations about law for the better before it burned itself out. (Why it 
burned itself out is another and longer story than I have room to tell here. The short answer is that there is always limited room for left-leaning thought in the legal academy, and by the mid-1990s that space came to be wholly occupied by the new movements for critical race, gender, and LGBT studies. Those intellectual movements had the advantage, which CLS definitely did not, of being allied with active movements for social and legal change outside the academy.) He points out that CLS was law-centric, and it certainly was: it originated as an internal critique of the way law was taught and written about in law schools and was designed to give law faculty and students alternative ways of thinking about law that would help pry them loose from what we saw as the conservatizing effects, the glum, resigned complacency about the political and social status quo, that we believed was induced by orthodox legal training. Most CLS work was critique of legal doctrine and law-and-economics-based policy argument, simply because most legal scholarship and teaching was about doctrine and policy. CLH was largely written as an exercise in internal critique, directed against standard historical narratives embedded in conventional legal argument and scholarship. It ranges beyond legal sources because, of course, most of these classic narrative lines originate in extra-legal sources and were imported from these into legal writing.

It turned out that this article found most of its audience in social and social-legal historians and law-and-society scholars, who were puzzled by what appeared to them to be, toward the end of the piece, a privileging of doctrinal histories of law. Social historians and social-legal scholars were committed by vocation to minimizing the importance of "law on the books" in society, and especially of formal juristic thought, at least as a causal element. Susanna Blumenthal points to a classic instance of this commitment, Friedman's brilliant polemical review of Perry Miller's Life of the Mind in America (Friedman 1977). So was this apparent turn to doctrine a reactionary move? Did it, as Tomlins suggests, invert the usual causal story of legal sociologists and social-legal historians that law is an effect of social forces and of social change and substitute ideal for material determination? Did it, as Edwards suggests, identify "law" with mandarin doctrine, and both with a self-contained autonomous field?

I see how the argument could be read that way, but I certainly did not intend that. To the charge of idealism, I'm quite sure I want to plead not guilty. When I wrote CLH, I was a committed Legal Realist and law-and-society person, and remain one still. I went to law school with an interest in legal history already formed because I had read F. W. Maitland and Willard Hurst. Like others of my generation I was frustrated to the point of fury with my own legal education, with the study of appellate doctrine with no attention to where it came from and what its connection was with the lives and struggles of people outside the legal system. (The early work in law and economics, by contrast, was actually refreshing because, however reductive and even goofy it might sometimes seem, it at least purported to be about real-world consequences of legal rules and decisions.) We learned almost nothing in law school about Legal Realism, except that it had taken skepticism about rules too far-certainly nothing about the empirical side of Legal Realism. Social-legal history in the modes of Richard Morris, Hurst, Friedman, and Harry Scheiber was attractive because it offered the potential to explain how legal rules and processes matter in context to the lives of ordinary people, as were the ascendant schools of social-legal history pioneered by E. P. Thompson and Douglas Hay in the 1970s. My own first real legal history papers were about church corporations 
in colonial New England and the ordinary uses of law by New York merchants after the Revolution. When I started teaching at Buffalo and Wisconsin, it was with colleagues like Marc Galanter, Stewart Macaulay, David Trubek, Jack Schlegel, and Hurst himself. I became friends early on with Scheiber and Friedman, and through their influence I absorbed the need to pay attention to the low-lying details of how law makes itself felt-or is ignored, minimized, or resisted-in everyday life.

In CLH I was not trying to privilege the history of legal doctrine over other kinds of legal history, not identifying "critical" history with the history of doctrine, and not even arguing that high-level doctrine determines or necessarily even influences the shape of law in every aspect of social life, although sometimes it surely does. All I was trying to do was to explain what a particular kind of critical legal history-the work pioneered by Duncan Kennedy and his circle on the history of contradictions in liberal legal thought—was all about and why it was worth doing. Kennedy's work had struck me and many others reading it for the first time as shockingly, brilliantly enlightening, and it made me at least reevaluate my prejudice going in that doctrine was mostly a sideshow. Theirs was anything but the usual sort of internalist doctrinal history that showed how a legal concept - such as "consideration" in contract doctrine-had developed from some medieval or Roman embryo into its splendidly mature form. This was history that showed how jurists came to assemble a whole coherent system of doctrine in the late-nineteenth century, and how that system cracked open under the pressure of its own contradictions, as well as savage political and intellectual attacks from outside. (I thought then and still do that the manner of relating that history looked misleadingly idealist because it was so much focused on the "internal contradictions" and so little on the "pressure from outside.") It was history that led me to appreciate the stakes, intellectual and political, that the managers of the legal system had in their own constructs. I have since found reinforcement for this view in legal histories such as Blumenthal's own work (Blumenthal 2006), where one finds judges, and the lawyers arguing before them, and the jurists synthesizing their product in treatises, mustering enormous intellectual effort to try to draw the boundaries between action for which civil and criminal defendants must be held responsible because they willed it, or excused from liability because they did not, building in the process marvelously complex sandcastles of categories of legally relevant states of mind and means of evidencing them. It is not enough to simply say, well, they had practical tasks to perform-settling disputes over property rights, will contests, or defenses to breach of contract such as of duress or undue influence. They also had the practical tasks of justifying their decisions, which was hard, and the justifications kept changing as circumstances changed and the old ones no longer seemed convincing. They created notional worlds that supposedly distinguished the mad from the bad and gave lawyers, policemen, asylum heads, adjudicators, caretakers, and greedy relatives some tests and categories for telling the difference. Some of these found their way, though often altered in the process, into everyday conceptions and practices.

The point I took from this work was not that the ideal caused the material, that out of conceptions in cases and treatises came "relations of production" and all the gritty experiences of social life. The point was, rather, that legal conceptions in various forms were omnipresent in those experiences. Dirk Hartog has just published a book (Hartog 2011) about relatives and strangers in the nineteenth century who came to care for old 
people, hoping or expecting to be rewarded with some property when the old person died. The courts were often called upon to decide whether the caring person should after all receive the property or some share of it, or whether it should go to the intestate heirs. To make and explain these decisions, the judges did what judges do: they built and applied an elaborate apparatus of categories and tried to squeeze the facts into one or another of them. The results were often perverse and cruel, since one of the features of that legal framework is that the most admirable and seemingly most deserving caregiver, the unselfish volunteer who sacrifices her life to another for love, is least likely to recover: she would have to pose before the court as a grasping opportunist to have a shot at receiving the farm.

But it is not just the judges who are applying legal categories, it is also the participants in the social drama, who are thinking "promise, contract, will, value-forwork done [quantum meruit], wife, child, non-relative"-albeit certainly not always in the way the courts do. The participants and the judges are drawing upon a common cultural stock of legal ideas, even though they may not always converge on how to interpret them. Tomlins refers to Laura Edwards's description of local law in her path-breaking People and Their Peace (Edwards 2009) as an example of radical discontinuity between informal regimes of local adjudication and official regimes of legal formality: it is that, but at the same time it shows how many legal conceptions (many of them derived from an older English law's hierarchy of status relations) are invoked in informal practice. In Edwards's story, professional lawyers saw what they interpreted as deviations from formal legality in the country courts as a problem to be overcome by making local practice subject to hierarchical controls (the "rule of law"). As Edwards points out, these lawyers' very distinctions between formal law and informal custom, between law effectively made by the claims and arguments of ordinary litigants and witnesses in local procedure and law made by lawyers and judges and officials, were actually something new. The lawyers proved to be largely successful in their project to transmit these distinctions and the hierarchical superiority of official law, but at the same time they were busily creating new zones of practical immunity where law exempted relations from law's writ or delegated law's power to a private person: in slavemasters' households, factory managers' domains, intimate marriage relations. As Robert Cover memorably argued (Cover 1983), local communities are always "jurisgenerative," making their own law. That law may eventually be absorbed into central state norms and practices or may be violently suppressed by them, but it is law nonetheless.

This line of thought - that the legal is embedded in the social-also drew heavily on various strands of Legal Realism. ${ }^{2}$ One strand, for which the customary cites are to

2. Tomlins asks, reasonably, why the essay steers clear of discussing Marxist ideas, which certainly influenced some people in CLS, as did various other bits of European social theory, although a rediscovered and revived Legal Realism was a greater influence. The answer lies in what one could call either prudence or cowardice. I often found the experience of argument with marxisant intellectuals too frustratingly much like arguing with theologians (or for that matter neoclassical economists), who (so it seemed to me) were sometimes more insistent on maintaining their theory than understanding the problems it sought to address: one could rapidly find oneself immersed in the details of interpretation of this or that piece of sacred text. The cowardly part was that there had already been a lot of Red-baiting of CLS and I wanted to establish its solid domestic foundations. (At a conference on law and economics in the 1980s I heard CLS accused of 
Robert Hale and Morris Cohen (Hale 1923; Cohen 1927), observes the pervasive structuration of social relations by regimes of legal rules. The state regulates "private" conduct though private law as much as it regulates through legislation and administration: the going rules of property-tort-contract delegate and distribute the powers to coerce and to organize; property gives the authority to subject others to the holder's rule; grants of legal immunities empower the grantees to inflict harm on others without penalty. Facts stated as premises of legal decisions, such as whether someone had possession of goods or had accepted an offer to contract, were often legal conclusions in disguise (see Corbin 1917; Cook 1935).

Another strand of Realism, the "indeterminacy" argument pushed by scholars such as Arthur Corbin (1950-1993) and Leon Green (1928-1929), argued that formal rules do not determine any unique set of applications: even if one does not look beyond case law doctrine, one can see that the contract-formation rules or the negligence standard are applied very differently across different factual contexts and time periods. CLS contributed a further idea to this Realist mix: that rules and principles were necessarily indeterminate because they were founded on contradictions. Indeterminacy in application was not the result only of overbreadth or malleability in legal concepts, or static noise (inertia, resistance, agents' opportunism, etc.) in transmission on the way to implementation, it was built right into the rules themselves. The law of wills sought both to preserve freedom of testation and to limit that freedom to prevent donees from tying up wealth (the "dead hand" problem) (Alexander 1985); contract law simultaneously sought to promote parties' freedom and to limit it to protect their security of expectations (Mensch 1982), to promote both an antisocial, self-interested individualism and a framework of trust and communal solidarity (Kennedy 1976). In periods when courts considered property rights absolute, they limited those rights to prevent collision with the equally absolute rights of others, thus making all the rights relative (Bone 1986).

In historical practice, doctrine both on the books and in application would oscillate between the poles of contradictory opposites, often to the point of breaking down the categories that lawyers, judges, and jurists kept building to manage contradiction (see generally Kelman 1987). The most dramatic example of such a breakdown-which was the master theme of Kennedy's very influential though until 2006 unpublished Rise and Fall of Classical Legal Thought-was of the public-private distinction, which became the dominant principle for organizing legal doctrines, from the great principles of constitutional limits on the police power to the minutiae of private-law doctrine (the difference between contracts implied "in law" and "in fact"), in the late-nineteenth century. Tie all these strands together and you arrive at the conclusions, emphasized in CLS, both that law is pervasively embedded in social life but that the forms of law cannot determine the forms of social life, any more than law can be systematically functional to material requirements of social life, because it is indeterminate in application and indeed in its very foundations.

being "un-American." "Un-American!" I responded indignantly. "That's rich, coming from a field whose prophets have names like Léon Walras, Eugen von Böhm-Bawerk, Knut Wicksell and Vilfredo Pareto! Our intellectual ancestors are good sound Americans!") 
The set of notions I have been pushing, that law is omnipresent in the marrow of social life, or that law is partly constitutive of social life, because law distributes powers and immunities, and because all social actors internalize and enact legal identities and roles, tends to get mixed up with another issue entirely, that of the relation between elite/official and everyday/lay legal actions. Quite often when legal sociologists speak of the relations between law and society, they are really talking about relations between different levels of law-in-society, and the differences and discontinuities between those levels. For example, when employees are asked, "Can your employers fire you just because they dislike you, or do they have to have a valid reason?", 89 percent or so of them answer, "No, they have to have a reason!", even though the official legal system says that employees at will can be fired for any reason or no reason (Kim 1997; Freeman and Rogers 1999). As the example illustrates, differences/discontinuities between levels hardly means that formal law "doesn't matter." In this particular case, the formal law is much more consequential than lay expectations of a just dismissal regime, which are constantly being disappointed, and the law is not gradually brought into harmony with popular expectations because employees have little political power and increasingly few judges and legislatures who sympathize with them.

And finally, the issue of the relation between elite doctrine and everyday practice in turn becomes blended into yet another question, whether the formal-official-level rules (the "mandarin" rules as CLH called them) are worth studying at all. Hurst, like many of the Realists, thought that legal scholarship tended to overemphasize the importance of mandarin law (especially federal Supreme Court decisions) and focused excessively on it. That critique was and still is hard to dispute, but it is not an argument for abandoning the study of mandarin law, only for studying law-embedded-in-everydaysocial-practice as well. In CLH, I made a half-hearted instrumental argument for studying mandarin law, which was that it was-or anyway might sometimes be-a purified and easily accessible distillation of legal concepts that were likely to be found in vernacular forms all across society. Of course, that is not inevitably true-the legal system sometimes wraps itself up like a mummy in hyper-formal elaborations of its doctrines, or mechanical rigidity in applying its rules or precedents, to the point where it is alien to what any sentient nonlawyer actor would think about any subject. This was more likely to happen in European legal culture, where high formalism was sustained by a prestigious academic caste of commentators, than in the United States, where elite judges and jurists came out of practice and even in the classical age (1870-1920) had a pretty shrewd and realistic sense of how porous law was to social and political influences (see Tamanaha 2010).

On reflection, I think my original half-hearted argument is not that far off base. The public-private distinction that one sees gradually coming to organize mandarin law in the nineteenth century also may be seen to organize many other forms of social-legal institutions. In treatises and opinions, contract (private voluntarily assumed obligation) comes gradually to be separated from tort and quasi-contract (state-imposed obligation), as the "private" sphere of "the market" comes to be distinguished from the "public" sphere of state "regulation." Similarly, what had been seen as mixed-publicprivate associations like families, corporations (business, charitable, and municipal), churches, and government offices become assigned-both in legal categorization and common speech-to private or public spheres. The distinction collapses in mandarin 
law at the same time as it is collapsing elsewhere in social life, as visible (legislative and administrative corporatist policies and regulations, Jim Crow, and then civil rights statutes, government grants, etc.) replace less visible forms of state action.

But one should not need to justify studying mandarin legal ideas by arguing that they trickle down to workaday practice. The notion that elite thought is not worth attending to because it is elite seems to be a product of the inverse class snobbery of the 1960s. As Blumenthal says, legal doctrine is independently interesting as an inquiry into how the mind structures understandings of social life; what it classifies as similar or different; how it draws the boundaries between the privileged, the legitimate, the normal, and the deviant; between freedom and coercion; between actions for which people are responsible because they chose them freely or could have avoided the risks they imposed and actions excused by incapacity, supervening causes, or inevitable accident. After all, we study the history of scientific thought, even when we think it has since been proved to be error; and economic thought, for the same reason; and ancient mythology and medieval theology. Mandarin law sometimes represents a fantasy of elites, an imagination of an ideal social order. In that way, it is like laissez-faire political-economic thought: utterly fantastic as a description of any actual regime of government action in any point in Americans' history or anyone else's, but a powerful fantasy, one that moves people to try to conform reality to it. A collection of essays (Fernandez and Dubber forthcoming) on the history of the quintessential mandarin art form, legal treatises, shows treatises being written for a multitude of purposes besides the high-flown attempt to demonstrate that law is a science of principles: to rationalize existing bodies of law as consistent with tradition, to modernize bodies of law or stealthily innovate by discarding disfavored doctrines as obsolete, to promote a nationalist agenda by minimizing differences across jurisdictions, to give colonial administrators a practical manual for governance, and to give law students and practitioners enough abstraction to enable clear-cutting of vast unruly forests of case law. How influential such treatises are probably varies a good deal from field to field, but it is hardly farfetched to suppose that legal practitioners, among the chief transmitters of law to clients, pick up and disseminate the categories and opinions of the treatise writers along with their summaries of rules and citations of cases (for such mechanisms of cultural transmission at work in child custody law, see Grossberg 1996, 231-39).

While offering this defense of CLS-style doctrinal history, though it mostly was not and is not the kind of history I do myself, I also tried to make an earnest plea for the study of law at the vernacular level, law "imbricated" (to use E. P. Thompson's excellent word) in structures and processes of everyday interaction among social actors. (Once again, imbricated law is not the same thing as vulgarized mandarin law, though sometimes it is exactly that.) To say that plea has been "heeded" would absurdly claim credit for what has happened since, but it is fair to say there has been an explosion of such work in social-legal history. (The vein of work on the history of contradictions in legal thought, by contrast, seems rather to have petered out.) As Blumenthal says, much of this work has been informed by the insight that law is "an arena of social struggle." To mention just a handful of obvious examples: Ariela Gross on the low-level legal processes for determining racial identity (2008); Richard Ross (1998) and Daniel Hulsebosch (2005) on the exfiltration of common law thought from mandarin lawyers into popular political ideology; Stephen Wilf (2010) on popular criminal justice; Laura 
Edwards (2009) on local-discretionary administration of justice as a means to produce communal order ("the peace"); Tomlins (1993), Steinfeld (2001), and Forbath (1991) on labor relations and organization and John Witt (2004) on responsibility for workplace accidents; Carol Rose on the commons as public property (1986); Friedman on inheritance law in action (2009) and morals regulation (2007); Nancy Cott (2000), Ariela Dubler (2003), and Hendrik Hartog (2000) on the legal construction of family life; William Novak (1996) on pervasive regulation through the police power; Rebecca Scott (2005) and Amy Stanley (1998) on "degrees of freedom" in work relations after slavery; Harold Woodman (1995) and Gerald Jaynes (1986) on the law of credit and labor in the agrarian Reconstruction South; Reva Siegel, Robert Post, Larry Kramer, James Pope, and Jack Balkin (Pope 1997; Kramer 2004; Balkin and Siegel 2006; Post and Siegel 2007; Siegel 2008) on popular constitution-making through social movements; Risa Goluboff (2007) on constitutional innovation through ground-level enforcement; and many, many more. Blumenthal says truly that this kind of work tends to be "cagey on causation," and it is certainly so on whether directions of influence tend to run from the bottom up or from the top down. Sometimes, one sees working-level social actors ignoring official law altogether, or bending it to their own purposes, or blending it with vernacular materials to produce new legal arguments that are then carried back up the system.

Laura Edwards brings to this symposium a fascinating report from the interior of the continent of history. Like Blumenthal, she sees that what I was trying to do in CLH was simply to import into legal studies some of the conventional attitudes and methods of historians-above all, their historicism, as exemplified in the "discursive turn" that "challenged universalizing narratives, reductive explanatory frameworks, and the construction of the discipline's most basic categories, namely, individuals and society." In a surprise twist, she then tells us that the main value of CLH for her teaching is as an antidote to certain persistent forms of functionalism in social historians' own practice. One of these is, if I read her right, a sort of pre-Legal-Realist assumption that a legal text is a clear window into a society's beliefs, a kind of privileged statement about how power operates-such that, for example, Blackstone's summary of the law of coverture as providing for the total subordination of wives in marriage is taken to be an authoritative exposition of wives' actual situation and status. ${ }^{3}$ Legal-social historians, by contrast, are much more likely to take such a text as a move in a complicated dance of interpretation engaged in by people acting in many different times and contexts, from many different positions of authority and influence, including wives themselves. At the same time as social historians reify legal texts, they mostly tend to ignore histories of law, treating them as apart from and irrelevant to social history-the same kind of blinkered perspective, but from the other side of the law/history divide, that the old internalist legal historians used to have.

Edwards also says that however historicist their methods when studying local contexts, social historians tend to fall back into reliance on grand evolutionary

3. See Maitland's memorable caution against the unreliability of legal sources as guides to social life: "We know well from our own history how apt were the lawyers of past ages to fuse the old with the new, to borrow rules from the most various sources, without telling us whether these rules were practicable or impracticable, living or dead, imported novelties or obsolescent survivals of a forgotten age" $(1911,4)$. 
narratives when heeding their discipline's imperative to generalize beyond particular times and places. At least, she points out, they have a bigger stock of narratives. Even the most conventional of historians' approaches to long-term history rely on narratives of decline as well as progress. Historians were more receptive than many lawyers were to Morton Horwitz's (1977) negative assessments of the effects of the legal framework supporting capitalist development because they were more accustomed to such arguments. To be sure, decline has always been a theme in US legal history as well-decline, for example, from the exemplary civic virtue of the Founders and their constitutional vision-but decline is generally a muted and subordinate theme. Decline has become more prominent recently in legal rhetoric as liberals lament the retreat of legal policy from the progressive accomplishments and social visions of the New Deal, Great Society, and Rights Revolution and conservatives lament the fall from libertarian and moral virtue attendant on the policies of the progressive, secularizing, and equality promoting social-welfare and regulatory state. Nevertheless, on the whole, lawyers' views of history remain triumphalist.

Indeed, Whiggish modernization theories have recently rebounded in force. The fall of the Soviet Union and the Iron Curtain brought flooding back EF narratives in particularly reductive and triumphalist forms. Now liberal capitalism on the US model was seen as the only viable outcome of modernization: the only choice of public policy in ex-Communist and developing societies was between market capitalism and stagnation. At first, the post-Iron-Curtain narratives ignored law, but after the failure of "shock therapy" in Russia reminded economists that "free markets" might depend on a supporting legal framework, Western thinking about development brought law back in.

The rule of law then came to be seen as crucial to modernization and the building of viable capitalist societies. The difference between dynamism and stagnation, prosperity and poverty boiled down to a few simple variables - legal variables. The rule of law in these formulations meant strict property rules and contract enforcement, preferably constitutionalized against political revision, to facilitate investment (especially foreign investment), Western models of corporate governance, and administration by courts rather than bureaucrats. The rule of law movements in their World Bank version borrowed loosely from Friedrich Hayek, the Chicago School of Law and Economics, and Douglass North (see Trubek and Santos 2006). One of their offshoots was the "legal origins" school of economic development, which postulated that common law systems such as those of England and her colonies were superior in efficiency as legal governance mechanisms to civil law systems, in part because their decision making was judicially administered and decentralized and they developed more flexible and facilitative legal models of business organization.

Historians, including legal historians, have not been kind to these models of the role of law in development, pointing out, for example, that the United States seemed to prosper in the nineteenth century either by means of, or despite, enacting high tariff barriers, constitutionalizing the legal protection of slavery, and using the courts to demolish traditional property rights (Scheiber 1973; Horwitz 1977; Upham 2002); that it was the common law, not the civil law before Napoleon, that was historically the more centralized system of the two (Klerman and Mahoney 2007); and that British common law was, in its complexity and procedural delays, more a source of despair than encouragement to dynamic business interests such as railroad entrepreneurs, who cried 
out for reliably predictable administrators to supplant the courts (Kostal 1990; Harris 2000); that French legal forms of nineteenth-century governance were actually more flexible than US ones (Lamoreaux and Rosenthal 2005); and that Asian tigers seemed to have grown wonderfully quickly without Western-style courts and private law, under the stimulus of an active state apparatus (see generally Ohnesorge 2007).

Some comparative economic historians have seriously undermined the theory that Western European (or more specifically, British) legal institutions, such as rules relating to commercial property, supplied a uniquely favorable environment for industrial development in the nineteenth century. They point out that China possessed similar advantages up until 1800, that both Europe and China faced similar land constraints that might have stifled their further growth, and that the crucial factors enabling European societies to break out of such constraints were their ability to expand into overseas colonies and the Atlantic slave trade (see Pomerantz 2000). Yet tendentious though they may have been, these new strains of EF theory have caused a fair amount of damage when reforms based on implementing them have been imposed as conditions on "structural adjustment" loans. Most often, to be sure, the rule of law initiatives, stymied by mismatches between the reform measures and local cultures and institutions and by resistance from entrenched legal professionals and other vested interests, have simply been ineffectual.

Finally, Edwards and Tomlins both raise the point that a strong antifunctionalist, antideterminist critique tends to dissolve the history of any social phenomenon into simply thick description, skeptical alike of grand narratives and indeed any accounts of causation. It is all very contingent, all very complicated. To the extent this does happen, it is a mixed blessing. It is the job of history-is it not?-to mess up and complicate the generalizing social sciences' models of how the world works with evidence that in one place or another actual developments skipped a stage in a model or went through the stages in reverse or bypassed the stages altogether. But life would be much poorer without comparative historical sociology, which tries to find patterns in small-stage particulars to come up with new theories about the role of legal ideas and arrangements in the constitution of social life-however provisional these theories may be, and however vulnerable to puncture by specialist historians' critiques of their details. In these continuing dialogues lies the only hope of advancing understanding.

Is Tomlins right that the appreciation of complexity leads into a cul-de-sac of political paralysis? This is an old question, which I could use more help in thinking about. My first instinct is to say no, with Maitland:

The only direct utility of legal history (I say nothing of its thrilling interest) lies in the lesson that each generation has an enormous power of shaping its own law. I don't think the study of legal history would make men fatalists; I doubt it would make them conservatives; I am sure that it would free them from superstitions and teach them that they have free hands. ${ }^{4}$

Maitland was writing against people who argued that departure from tradition was risky and unwise ("conservatives") and people who thought social forces beyond any society's 
political control determined the course of history ("fatalists"). As a historicist, he thought most of what conservatives identified as tradition was of relatively recent origin and also, since it was inevitably and anachronistically seen through modern eyes, a distortion of an unreproducible past. He would have thought constitutional "originalism" a quixotic and unachievable project. As a skeptic about theories of uniform paths of development, he believed that different societies had made contingent choices at crucial moments that had led them to different outcomes, and would continue doing so in the future. Of course, any history that emphasizes, as Maitland's did and as "critical" historians also do, that legal change often results in ironic or perverse consequences, such as reactionary backlash or incremental tinkering that co-opts or buys off insurgent movements and thus preempts more sweeping reforms, might induce in its readers complete paralysis rather than the urgent inspiration to reshape the law. All history can tell us is that opportunities for remaking law always exist and, if seized in a spirit of adventure and pragmatic experiment, may sometimes lead to better states of the world than those we have come to accept out of complacency or despair.

\section{REFERENCES}

Alexander, Gregory. 1985. The Dead Hand and the Law of Trusts in the Nineteenth Century. Stanford Law Review 37:1189-266.

Aron, Raymond. 2004. Main Currents in Sociological Thought (2 vols.). New Brunswick, NJ: Transaction Publishers.

Balkin, Jack, and Reva Siegel. 2006. Principles, Practices and Social Movements. University of Pennsylvania Law Review 154:927-50.

Blumenthal, Susanna. 2006. Deviance of the Will: Policing the Boundary of Testamentary Freedom in Nineteenth Century America. Harvard Law Review 119:960-1035.

Bone, Robert G. 1986. Normative Theory and Legal Doctrine in American Nuisance Law. Southern Califormia Law Review 59:1101-226.

Burrow, John. 1966. Evolution and Society: A Study in Victorian Social Theory. Cambridge: Cambridge University Press.

Cohen, Morris. 1927. Property and Sovereignty. Comell Law Quarterly 13:8-30.

Cook, Walter Wheeler. 1935. Rescission of Bargains Made on Sunday. North Carolina Law Review 13:165-95.

Corbin, Arthur. 1917. Offer and Acceptance and Some of the Resulting Legal Relations. Yale Law Joumal 26:169-206.

-1950-1993. Corbin on Contracts: A Treatise on the Working Rules of Contract Law. St. Paul, MN: West Publishing.

Cott, Nancy. 2000. Public Vows: A History of Marriage and the Nation. Cambridge, MA: Harvard University Press.

Cover, Robert. 1983. Nomos and Narrative. Harvard Law Review 87:4-68.

Dubler, Ariela. 2003. In the Shadow of Marriage: Single Women and the Legal Construction of Family and the State. Yale Law Joumal 112:1641-716.

Edwards, Laura. 2009. The People and Their Peace. Chapel Hill: University of North Carolina Press.

Fernandez, Angela, and Markus Dubber, ed. Forthcoming. The Treatise in Legal History.

Forbath, William. 1991. Law and the Shaping of the American Labor Movement. Cambridge, MA: Harvard University Press.

Freeman, Richard B., and Joel Rogers. 1999. What Workers Want. Ithaca, NY: Russell Sage Foundation.

Friedman, Lawrence M. 1977. Book Review: Heart Against Head; Perry Miller and the Legal Mind. Yale Law Journal 77:1244-59. 
- 2007. Guarding Life's Dark Secrets: Legal Controls over Reputation, Propriety and Secrecy. Stanford, CA: Stanford University Press.

—. 2009. Dead Hands: A Social History of Wills, Trusts and Inheritance Law. Stanford, CA: Stanford University Press.

Green, Leon. 1928-1929. The Duty Problem in Negligence Cases. Columbia Law Review 28:1014-45; 29:255-84.

Goluboff, Risa. 2007. The Lost Promise of Civil Rights. Cambridge, MA: Harvard University Press.

Gross, Ariela. 2008. What Blood Won't Tell: A History of Race on Trial in America. Cambridge, MA: Harvard University Press.

Grossberg, Michael. 1996. A Judgment for Solomon: The D'Hauteville Case and Legal Experience in Antebellum America. Cambridge: Cambridge University Press.

Hale, Robert M. 1923. Coercion and Distribution in a Supposedly Non-Coercive State. Political Science Quarterly 38:470-78.

Harris, Ron. 2000. Industrializing English Law: Entrepreneurship and Business Organization, 1720-1844. Cambridge: Cambridge University Press.

Hartog, Hendrik. 2000. Man and Wife in America: A History. Cambridge, MA: Harvard University Press.

- 2011. Someday All This Will Be Yours: A History of Inheritance and Old Age. Cambridge, MA: Harvard University Press.

Horwitz, Morton J. 1977. The Transformation of American Law, 1780-1860. Cambridge, MA: Harvard University Press

Hulsebosch, Daniel. 2005. Constituting Empire: New York and the Transformation of Constitutionalism in the Atlantic World, 1664-1830. Chapel Hill: University of North Carolina Press.

Hurst, James Willard. 1956. Law and the Balance of Power in the Nineteenth Century United States. Madison: University of Wisconsin Press.

Jaynes, Gerald. 1986. Branches Without Roots: Genesis of the Black Working Class in the American South, 1862-1882. New York: Oxford University Press.

Kelman, Mark. 1987. A Guide to Critical Legal Studies. Cambridge, MA: Harvard University Press.

Kennedy, Duncan. 1976. Form and Substance in Private Law Adjudication. Harvard Law Review 89:1675-778.

2006. The Rise and Fall of Classical Legal Thought. Washington, DC: Beard Books.

Kim, Pauline T. 1997. Bargaining with Incomplete Information: A Study of Worker Perceptions of Legal Protection in an At-Will World. Cornell Law Review 83:105-60.

Klerman, Daniel, and Paul Mahoney. 2007. Legal Origin? Journal of Comparative. Economics 35:27893.

Kostal, Rande. 1990. Law and English Railway Capitalism, 1825-1875. Oxford: Clarendon Press.

Kramer, Larry D. 2004. The People Themselves: Popular Constitutionalism and Judicial Review. New York: Oxford University Press.

Lamoreaux, Naomi, and Jean-Louis Rosenthal. 2005. Legal Regime and Contractual Flexibility: A Comparison between Businesses' Organizational Choices in France and the United States during the Era of Industrialization. American Law \& Economics Review 7:28-61.

Maitland, F. W. 1911. Review of Seebohm. In Tribal System in Wales. Collected Papers, ed. H. A. L. Fisher, vol. 3, 1-10. Cambridge: Cambridge University Press.

—. 1965-1995. Letters of Frederic William Maitland. Ed. C. H. S. Fifoot and P. N. R. Zutschi. London: Selden Society.

Mensch, Elizabeth. 1982. The History of Mainstream Legal Thought, in The Politics of Law: A Progressive Critique, ed. D. Kairys, 18-37. New York: Pantheon Books.

Novak, William J. 1996. The People's Welfare: Law and Regulation in Nineteenth-Century America. Chapel Hill: University of North Carolina Press.

Ohnesorge, John K. M. 2007. The Rule of Law. Annual Review of Law \& Social Science 3:99-114.

Parker, Kunal M. 2011. Common Law, History and Democracy in America, 1790-1990. New York: Cambridge University Press.

Pomerantz, Kenneth. 2000. The Great Divergence: China, Europe and the Making of the Modern World Economy. Princeton, NJ: Princeton University Press. 
Pope, James Gray. 1997. Labor's Constitution of Freedom. Yale Law Joumal 106:941-1032.

Post, Robert, and Reva Siegel. 2007. Roe Rage: Democratic Constitutionalism and Backlash. Harvard Civil Rights-Civil Liberties Law Review 42:373-434.

Pound, Roscoe. 1909. Liberty of Contract. Yale Law Journal 18:454-87.

Rabban, David M. 2010. Rethinking Classical Legal Thought. Unpublished manuscript.

Rose, Carol. 1986. The Comedy of the Commons. University of Chicago Law Review 53:711-81.

Ross, Richard. 1998. The Commoning of the Common Law. University of Pennsylvania Law Review 146:323-462.

Rostow, Walt W. 1960. The Stages of Economic Growth. New York: Cambridge University Press.

Rubin, Paul H. 1977. Why Is the Common Law Efficient? Joumal of Legal Studies 6:51-63.

Scheiber, Harry N. 1973. Property Law, Expropriation, and Resource Allocation by Government: The United States, 1789-1910. Joumal of Economic History 33:232-51.

Scott, Rebecca. 2005. Degrees of Freedom: Louisiana and Cuba after Slavery. Cambridge, MA: Harvard University Press.

Siegel, Reva. 2008. Dead or Alive: Originalism as Popular Constitutionalism in Heller. Harvard Law Review 122:121-245.

Siegel, Stephen A. 1990. Historism in Late Nineteenth-Century Constitutional Thought. Wisconsin Law Review 1990:1431-1548.

Smith, Adam. [1776] 1979. An Inquiry into the Nature and Causes of the Wealth of Nations. Ed. D. Campbell and A. S. Skinner. Oxford: Clarendon Press.

Stanley, Amy Dru. 1998. From Bondage to Contract: Wage Labor, Marriage, and the Market in the Age of Slave Emancipation. New York: Cambridge University Press.

Stein, Peter. 1980. Legal Evolution: The Story of an Idea. New York: Cambridge University Press.

Steinfeld, Robert. 2001. Coercion, Contract and Free Labor in the 19th Century. New York: Cambridge University Press.

Tamanaha, Brian. 2010. Beyond the Formalist-Realist Divide: The Role of Politics in Judging. Princeton, NJ: Princeton University Press.

Tomlins, Christopher. 1993. Law, Labor and Ideology in the Early American Republic. New York: Cambridge University Press.

Trubek, David. 1972. Max Weber on Law and the Rise of Capitalism. Wisconsin Law Review 1972: $720-53$.

Trubek, David, and Alvaro Santos, ed. 2006. The New Law and Economic Development: A Critical Appraisal. New York: Cambridge University Press.

Upham, Frank. 2002. Mythmaking in the Rule of Law Orthodoxy. Carnegie Endowment Rule of Law Working Papers 30.

Wilf, Stephen. 2010. Law's Imagined Republic: Popular Politics and Criminal Justice in Rewolutionary America. New York: Cambridge University Press.

Witt, John Fabian. 2004. The Accidental Republic: Crippled Workingmen, Destitute Widows, and the Remaking of American Law. Cambridge, MA: Harvard University Press.

Woodman, Harold. 1995. New South, New Law: The Legal Foundations of Credit and Labor Relations in the Post-Bellum Agricultural South. Baton Rouge, LA: LSU Press. 